\title{
Audit committee characteristics and accounting conservatism: An empirical investigation
}

\author{
Prepared by \\ Nisreen Mohammed Said Almaleeh \\ Accounting department, Faculty of Commerce \\ Menofia University \\ nesreen.mohamed@commerce.menofia.edu.eg \\ almaleehn@yahoo.com
}

Scientific Journal for Financial and Commercial Studies and Researches (SIFCSR)

Faculty of Commerce - Damietta University

Vol.3, No.1, Part 1., January 2022

APA Citation:

Almaleeh, N. M. S. (2022). Audit committee characteristics and accounting conservatism: An empirical investigation, Scientific Journal for Financial and Commercial Studies and Research, Faculty of Commerce, Damietta University, 3(1)1, pp.1-33

Website: https://cfdi.journals.ekb.eg/ 
Scientific Journal for Financial and Commercial Studies and Researches

(SJFCSR) Faculty of Commerce - Damietta University

\title{
Audit committee characteristics and accounting conservatism: An empirical investigation
}

\author{
Nisreen Mohammed Said Almaleeh
}

\begin{abstract}
The purpose of this paper is to examine the association between Audit committee characteristics (expertise, independence, size, and activity) and accounting conservatism in the Egyptian setting. To achieve this purpose, data is collected from the annual reports and board of director's reports of the companies included in the sample which is composed of 11 companies that belong to five main sectors: real estate, basic resources, IT, media and communication, non-bank financial services, and textile and durables sector. These companies are listed in the Egyptian Stock Exchange (EGX) during the period from 2015 to 2019. Two regression models were developed to test the research hypotheses. Results show that audit committee expertise is positively associated with the degree of accounting conservatism in the Egyptian listed firms' financial statements, while this association is not proven for audit committee independence, size, or activity. The findings have implications for Egyptian standard-setters and regulators, Egyptian firms and investors in Egypt and other developing countries.
\end{abstract}

Keywords: Audit committee independence, Audit committee expertise, Audit committee size, Audit committee activity, accounting conservatism 


\section{Nisreen Mohammed Said Almaleeh}

\section{Introduction}

In recent years, governments and regulatory bodies have paid greater attention to corporate governance standards, this situation came as a result of the global scandals which led to the fall of some international well-established firms. Corporate governance regulations were set with the aim of retrieving lost confidence in financial reporting (Habbash\& Alagla, 2016). Among the key components of the corporate governance mechanisms is audit committee which is increasingly recognized as a key factor in overseeing, monitoring, and advising the management for better implementing of internal control systems and preparing more reliable financial statements (Arun et.al. 2015; Sun et.al. 2011). This role can help in protecting owners' wealth, stopping managers maximizing their personal interests, and attracting more foreign investments (Ika\& Ghazali, 2012; Bansal\& Sharma, 2016)

Over the past decade, there has been a great agreement among both academics and standard setters about the necessity of the improvement of the configuration of the audit committee. The independence of audit committees is required for listed companies in most countries (Abad\& Bravo, 2018). Besides; corporate governance standards establish that the audit committee, which must consist of at least three members, must have one financial expert at least. In addition to that, numerous prior researches agrees that the frequency of audit committee meetings enables the audit committee members to have recent information about accounting and auditing issues of the firm, and this important to manage internal and external audit resources for addressing any problems in a timely manner. (Akhor\& Oseghale,2017).

The necessity of audit committee formation can be explained by the agency theory, which focuses on the relationship between principles and agents. This theory suggests that agency costs arise from the separation of ownership from control since managers (agents) will not always act in the best interests of principals (shareholders). To reduce the agency costs, shareholders will bear monitoring costs which enables the principal to better observe the agent's actions and to prevent the agent from taking the actions that would reduce firm's value (Zalata et.al.,2018). These expenditures include costs of hiring board members that will form subcommittees such as the audit committee. Audit committees are a 
Scientific Journal for Financial and Commercial Studies and Researches

(SJFCSR) Faculty of Commerce - Damietta University

substantial part of corporate governance as they are a monitoring mechanism that connects different parties involved in the financial reporting process and they are expected to provide effective monitoring which protects the principals' interests. To be effective, the members of the audit committee are expected to have certain qualities such as financial expertise and independence.

Accounting conservatism has influenced accounting practice and theory for centuries (Basu, 1997). Conservative accounting practices can reduce potential earnings manipulation by management who may deliberately increase earnings by choosing aggressive accounting practices for the recognition of good news in the financial statements. (Muttakin et.al.,2019). Investors' decisions are known to rely on reported financial information, and investors are more sensitive to a decline than an increase in firm value (Basu, 1997). Hence, the Timely recognition of bad news in earnings is agreed to be consistent with high-quality accounting practices compared to overly aggressive accounting practices that are implemented to overstate a company's financial performance (Watts, 2003; Francis et. al., 2005; Ball\& Shivakumar, 2006).

Traditionally, previous studies have reported that corporate governance complements conservatism in that it promotes conservatism to be adopted in financial reporting. A number of previous studies which examined the association between board characteristics and the quality of financial reporting have reported a positive association. For example, Levitt (2004) reported a positive relationship between the percentage of outside directors and analyst ratings of financial reporting quality, Faber (2005) found that the percentage of outside directors is negatively related to the likelihood of fraud and Xie et al. (2003) reported a negative relationship between the percentage of outside directors and the proxies of earnings management.

More specifically, previous literature suggests that the audit committee role in promoting higher-quality accounting practices is important. Literature suggests that audit committee quality is positively associated with firm's disclosure levels (Garcia-Meca \& SanchezBallesta, 2010; Verriest et al, 2012). Earlier studies also suggest that the audit committee effectiveness is positively associated with financial reporting quality (Klein, 2002). Additionally, the audit committee 


\section{Nisreen Mohammed Said Almaleeh}

effectiveness is proven to be negatively associated with committing of fraud (Abbott et al., 2004; Carcello et al., 2011). What is not yet clear is the impact of audit committee effectiveness on accounting conservatism, especially in the Egyptian context.

Focusing on the Egyptian context, in which this study is carried out, The Corporate Governance Code was first released in 2005 basically addressing listed companies to help them comply with governance and disclosure requirements. In 2011, The Corporate Governance Code was revised in line with the governance guidelines at the time, it recommended that the various controls in companies be activated, and it tackled Corporate Social Responsibility (CSR). The most recent amendment of the The Corporate Governance Code was released in 2016 placing greater emphasis on the role of board of directors as a key element in managing and directing the company, the code also illustrates the different types of board committees that assist the board in performing its functions and duties (The Egyptian Corporate Governance Code, 2016).

Among these board committees is the audit committee which is set up by the board of directors. The Egyptian Corporate Governance Code determined the duties of the audit committee in addition to its composition; it stated that the audit committee is made up of independent non-executive members of the board of directors, or from outside the company, provided that at least one of them has financial and accounting expertise.

In the light of the above, the major objective of this study is to investigate the effect of audit committee characteristics on the degree of conservatism in the financial reports of the Egyptian companies.

\section{Literature review and hypotheses development}

There is a large volume of published studies describing the role of corporate governance mechanisms in improving financial reporting quality. In this section of the study, previous literature is going to be classified into three main subdivisions; the first will discuss the previous literature concerning the association between corporate governance and financial reporting quality, the second will discuss the previous literature 
Scientific Journal for Financial and Commercial Studies and Researches

(SJFCSR) Faculty of Commerce - Damietta University

about accounting conservatism, and the last one will discuss the measures of audit committee characteristics.

\section{Previous literature about the association between corporate governance and financial reporting quality}

Over the last decade, studies on corporate governance have received much academic and business attention (Gilan, 2006).In these studies, discussions on the association between corporate governance and financial reporting quality have examined various issues such as the size of the board of directors, the executive director's participation, the proportion of board independence, and the gender of the members of the board of directors (Anderson et.al.,2004; Adams et.al.,2010; GarciaSanchez et. al,2017; Zalata et.al.,2018). Another group of studies examined the association between board characteristics and the quality of financial reporting; for example, Dechow et. al. (1996), Beasly et. al, (2000), and Farber (2005) found that the percentage of outside directors is inversely related to the likelihood of fraud, Klien (2002) and Xie et.el.(2003) reported a negative relationship between the percentage of outside directors and earnings management, a positive relationship between the percentage of outside directors and analysts' ratings of financial reporting quality was proven by Wright (1996)

Board of directors is considered one of the most important mechanisms of corporate governance, it is expected to reduce information asymmetry among stakeholders, reduce conflicts with regulators, and ensure the fulfilment of legal responsibilities (De Andres\& Vallelado, 2008). Garcia-Sanchez et. al (2017) demonstrated that effective board of directors with good governance practices is expected to use conservative accounting to assist them in managing agency conflict and in producing transparent financial reporting. Additionally, boards are responsible for monitoring the quality of information presented in the financial reports because managers usually have their own interests and incentives with regard to earnings management which would mislead stakeholders (Vafeas, 2000).

Focusing on audit committees, as a main concern of this study, a large and growing body of literature has investigated the relationship between audit committee quality and financial reporting quality reaching 


\section{Nisreen Mohammed Said Almaleeh}

to similar results as those of the association between board of directors and financial reporting quality. Mostly, prior research suggests that audit committee quality will improve financial reporting quality by reducing the probability of fraudulent financial reporting, incidence of accounting irregularities, and earnings management (Rainsbury et. al., 2009). Audit committee quality was proxied using multiple indicators; some studies suggested that independent and active audit committees with accounting expertise undertake activities that enhance the audit function because they are more likely to support the internal audit function, appoint industry specialist auditors, and they are less likely to have internal control problems (Abbott\& Parker, 2000; Raghunandan et.al, 2001; Abbott\& Parker, 2002; Krishnan, J. (2005). Another group of studies focused on audit committee financial expertise as a key determinant of audit committee quality, these studies found a negative relationship between audit committee financial expertise and earnings management, thus leading to higher quality financial reporting (Lin\& Hwang, 2010; Inaam \& Khamoussi, 2016).

\section{Previous literature about accounting conservatism}

Basu (1997) defined accounting conservatism as the asymmetric timeliness in the recognition of good news versus bad news in earnings. More specifically, accounting conservatism responds to unrealized losses more quickly than to unrealized gains, requiring a higher degree of verification of good news than of bad news (Muttakin et. al., 2019). Accordingly, it ensures that the accounting numbers used to determine cash flows are estimated conservatively and this can be an effective mechanism of reducing agency problem as it controls the opportunistic behaviour of management by reducing their ability to overstate earnings and net assets (Watts, 2003). Additionally, it can discourage management to invest in negative NPV projects or investments that perform poorly because of their inability to defer recognition of losses to the future (Ball\& Shivakumar, 2005).

The concept of accounting conservatism has been proven to have a positive effect on the financial reporting quality and the usefulness of accounting information. For example, it was found to improve the value relevance of earnings, leading to lower earnings management, and lower cost of debts (Lin,2006; LaFond \& Watts, 2008; Zhang, 2008). 
Scientific Journal for Financial and Commercial Studies and Researches

(SJFCSR) Faculty of Commerce - Damietta University

Accounting conservatism was also found to be positively associated with the improvement of corporate information environment (Hu et. al., 2014), it enhances the usefulness of financial statements for users of accounting information by reducing residual losses that can arise from asymmetric information between managers and external users (Ahmed\& Duellman, 2007).

Several studies thus far have linked accounting conservatism to good corporate governance mechanisms, Bushman\& Piotroski (2006) observed that firms in countries with stronger investor protection reflect bad news in reported earnings numbers more timely than do firms in countries characterized by weaker systems of investor protection. Ahmed\& Duellman (2007) found that firms with a higher proportion of outside directors recognize losses on a timelier basis than firms with a lower proportion of outside directors, Cullinan et. al. (2012) found that accounting conservatism is negatively associated with managerial ownership. Leventis\& Owusu - Ansah (2013) observed that banks with effective governance structures practice higher levels of accounting conservatism. In the same vein, Lim (2011) has examined the effect of different governance attributes on accounting conservatism and reached a conclusion that board independence and separation of the roles of CEO and chairman of the board of directors are positively associated with conservative accounting.

\section{Previous literature about audit committee characteristics.}

Most of the previous research about audit committees is guided by the agency theory which suggests that agency costs arise as a result of the separation of ownership from control because managers will not always act in the best interests of the shareholders.to reduce agency costs, shareholders incur monitoring costs which enables them to better observe the actions of managers and prevent them from taking actions that may reduce the firm's value (Jensen\& Meckling, 1976). These monitoring costs include expenditures of hiring board members who will form subcommittees including the audit committee. Previous literature confirms that the audit committee will be more effective if it has certain characteristics such as independence, financial expertise, sufficient size, and activities (Rochmah Ika\& Mohd Ghazali, 2012; Ghafran\& Yasmin, 


\section{Nisreen Mohammed Said Almaleeh}

2018). These studies, among others, revealed that the audit committee effectiveness, which is achieved by its characteristics, reduces the time of audit work, enhances the timeliness of financial information, and increases the financial reporting quality.

Many researchers attempted to explain why audit committee financial expertise may improve monitoring effectiveness, for example, Gore et. al. (2011) suggested that effective monitoring requires a high degree of specialized financial knowledge which supports the ability to evaluate managerial decisions, and without this financial training and experience, directors cannot determine whether the financial policies of the firm are appropriate, even if they have adequate incentives to monitor. Harris\& Raviv (2006) also suggests that financial experts are able to monitor senior management efficiently because they incur lower costs for acquiring information about the complexity and associated risks of financial transactions. As was noted by Krishnan\& Visvanathan (2008), audit committee members with financial expertise enhance accounting conservatism for several reasons; their monitoring and knowledge capabilities, job expectations as demanded by audit committee charter, and economic incentives for mitigating the litigation risk and protecting reputational capital.

In Egypt, the latest version of The Egyptian Corporate Governance Code which was released in 2016 stated that the audit committee must include at least one member with financial expertise. And as the association between the financial expertise of audit committee members and accounting conservatism has not been examined in the Egyptian context, the first hypothesis of this study is formulated as follows:

H1: there is a positive association between the financial expertise of the directors who serve in the audit committees of the Egyptian firms and the degree of accounting conservatism in their financial statements.

The Egyptian Corporate Governance Code (2016) requires audit committee independence, it stated that the audit committee must be made up of independent non-executive members of the board of directors, or from outside the company. The notion behind this requirement is that an independent audit committee makes better monitors. On the other hand, empirical evidence on whether independent audit committees play an 
Scientific Journal for Financial and Commercial Studies and Researches

(SJFCSR) Faculty of Commerce - Damietta University

effective monitoring role is mixed; some studies concluded a positive association between them, while other studies reported the opposite. for example, Beasley (1996) and Dechow et.al. (1996) suggested that a higher level of outside directors in the board decrease the probability of fraudulent information in the financial statements. Similarly, Klein (2002) concludes that independent audit committees are less likely to be associated with abnormal accruals. In addition, Abbott et. al. found a significant negative association between the occurrence of restatement and the audit committee independence.

However, many other studies argued that boards with higher insider representation play a more effective monitoring role. For example, Fama\& Jensen (1983) argued that inside directors can provide boards with more valuable information because they possess more firm-specific visions. In the same vein, Bhagat\& Black (2001) suggested that inside directors play valuable roles that might be absent in a single-minded drive for greater board independence.

As the association between independent audit committees and effective monitoring role which increases the financial reporting quality is not yet clear, the second hypothesis of this study is formulated as follows:

H2: there is a positive association between the independence of the directors who serve in the audit committees of the Egyptian firms and the degree of accounting conservatism in their financial statements.

Several studies have reported that audit committees with sufficient size are better able to deal with the companies' issues in an effective way (Sultana et. al., 2015). Although the Egyptian Corporate Governance Code (2016) did not specify the minimum number of members in the audit committee, most of the corporate governance codes around the world stipulate that audit committee should include at least three directors. For example, The Blue Ribbon Committee on Improving the Effectiveness for U.S. based corporations recommended that an audit committee should comprise of a minimum of three directors (BRC,1999).

The effect of audit committee size on the financial reporting quality has been the subject of debate within the research community; some studies found that the monitoring effectiveness can be enhanced by 


\section{Nisreen Mohammed Said Almaleeh}

smaller audit committee size due to better group cohesion, this conclusion was reached because of the argument that an increase in the audit committee size may result in less active participation by some members, which may in turn impair group cohesion and undermine the controlling and monitoring functions (Lipton\& Lorsch,1992; Hillman\& Dalziel, 2003).in the same vein, Jensen (1993) concluded that a larger committee functions less effectively and is easier for the CEO to control, Beasely (1996) also demonstrated that as committee size increases, the likelihood of financial statements fraud increases.

In contrast, other studies argued that larger boards may be more valuable for a higher degree of available knowledge and experience which enhances the overseeing quality (Xie et.al., 2003; Shukeri\& Islam,2012). Additionally, Chaganti et. al. (1985) suggested that a larger committee is more effective in prohibiting corporate failure. Based on the above discussion which has reached inconclusive results, the following hypothesis is developed:

H3: there is a positive association between the size of the audit committees of the Egyptian firms and the degree of accounting conservatism in their financial statements.

A number of researchers have reported that the frequent meetings of audit committees enable them to take many timely protective and corrective measures regarding weaknesses of internal control (Khlif $\&$ Samaha, 2016). This would enable the audit committee to detect and prevent the opportunistic behaviour of management and ensure the integrity of earnings and quality of reported accounting information (Bedard et. al., 2004). Menon \& Williams (1994) suggested that an independent audit committee may not be effective unless it is active. Similarly, Krishnan (2005) suggested that number of meetings reflects how proactive an audit committee is.

Regulators around the world have often recommended an active audit committee with frequent meetings during the year. For instance, The Blue Ribbon Committee (1999) reported that the audit committee should meet at least four times per year. Also, The Guidance on Audit Committees in the UK reported that an audit committee should meet three times a year at least. Although previous literature recommends that 
Scientific Journal for Financial and Commercial Studies and Researches

(SJFCSR) Faculty of Commerce - Damietta University

an audit committee that intends to play its role efficiently needs to maintain a high level of activity by meeting frequently and recording its conclusions to discharge its duties and responsibilities (Naimi et. al., 2010), The Egyptian Corporate Governance Code (2016) did not specify the minimum required number of audit committee meetings. Based on this theoretical predictions and empirical evidence, the following hypothesis is formulated:

H4: there is a positive association between the activity of audit committees of the Egyptian firms and the degree of accounting conservatism in their financial statements.

\section{Methodology}

\section{Sample selection and data sources}

The sample of this study consists of the most actively traded companies listed in the Egyptian Stock Market over the period that spans from 2015 till 2019 (the latest available data at the time of conducting this study). Three main criteria are employed for the inclusion in the sample:

(a) The company must have been listed in the EGX30 for the entire period 2015 till 2019

(b) Annual reports and board of director's reports of each company must be available.

(c) The company can be included in any sector except the banks sector as banks are governed by special disclosure requirements in Egypt.

The initial sample includes 13 firms; one firm is excluded because it belongs to the financial institutions sector and another one is excluded due to the unavailability of data about the board of directors and the audit committee characteristics. The final sample is composed of 11 companies which belong to five main sectors: real estate, basic resources, IT, media and communication, non-bank financial services, and textile and durables sector. The following table presents more details about the study sample. 
Nisreen Mohammed Said Almaleeh

\begin{tabular}{|c|c|c|c|}
\hline \multicolumn{4}{|c|}{$\begin{array}{c}\text { Table } 1 \\
\text { Sample distribution by sector }\end{array}$} \\
\hline Industry & Company & $\begin{array}{c}\text { No. of } \\
\text { companies } \\
\text { in the } \\
\text { sample } \\
\end{array}$ & $\begin{array}{l}\text { Percentage to } \\
\text { total companies } \\
\text { in the sample }\end{array}$ \\
\hline Real estate sector & $\begin{array}{l}\text { TMG Holding } \\
\text { Palm Hills } \\
\text { developments } \\
\text { SODIC } \\
\text { Madinet Nasr } \\
\text { Housing } \\
\end{array}$ & 4 & $36.4 \%$ \\
\hline $\begin{array}{l}\text { Basic resources } \\
\text { sector }\end{array}$ & $\begin{array}{l}\text { Ezz Steel } \\
\text { ELsewedy Electric }\end{array}$ & 2 & $18.2 \%$ \\
\hline $\begin{array}{l}\text { IT, media and } \\
\text { communication } \\
\text { sector }\end{array}$ & $\begin{array}{l}\text { Telecom Egypt } \\
\text { Global telecom } \\
\text { Holding }\end{array}$ & 2 & $18.2 \%$ \\
\hline $\begin{array}{l}\text { Non-bank financial } \\
\text { services sector }\end{array}$ & $\begin{array}{l}\text { EFG Hermes } \\
\text { Holding } \\
\text { Pioneers Holding }\end{array}$ & 2 & $18.2 \%$ \\
\hline $\begin{array}{l}\text { Textile and durables } \\
\text { sector }\end{array}$ & $\begin{array}{l}\text { Arabia Cotton } \\
\text { Ginning }\end{array}$ & 1 & $9 \%$ \\
\hline Total & & 11 & $100 \%$ \\
\hline
\end{tabular}

\section{Variables : measurement}

\section{Audit committee characteristics}

As the independent variable, audit committee characteristics include four variables; the first variable measures financial expertise. This variable $A C E X P$ is measured by the number of audit committee members with financial expertise divided by the total number of audit committee members, the second variable is audit committee independence $A C I N D$, this variable is measured by the proportion of 
Scientific Journal for Financial and Commercial Studies and Researches

(SJFCSR) Faculty of Commerce - Damietta University

independent directors to total number of directors on the audit committee. The third variable is the size of the audit committee ACSZ which is measured by the total number of Audit Committees members. The fourth variable is the audit committee activity $A C A C$ which is measured by the number of meetings held by the audit committee in a financial year.

\section{Accounting conservatism}

Much of the current literature on accounting conservatism pays particular attention to its measurement. The most commonly used measures in accounting literature are; Basu's (1997) which is based on the asymmetric timeliness of earnings, Ball and Shivakumar (2006) which employed the asymmetric-accruals-to-cash-flow, Beaver and Ryan (2000) which introduced market-to-book ratio as a measure of accounting conservatism, Penman and Zhang (2002) which suggested the measure of hidden reserves, and Givoly and Hayn (2000) which introduced the measure of negative accruals.

For the purpose of measuring accounting conservatism, the measure of Beaver and Ryan (2000) is used for the following reasons; the ease of computing and applying it, it is a comprehensive measure that covers both conditional and unconditional conservatism, it reflects the cumulative effect of accounting conservatism, and it connects data in the financial statements to market data (Feltham and Ohlson, 1995; Zhang, 2000; Beaver and Ryan,2000). According to this measure, accounting conservatism is measured by the market value of equity divided by the book value of equity. If it is equal to 1 , this indicates that there is no degree of applying accounting conservatism. If its value exceeds 1, this indicates that the market value of equity is more than its book value, which reveals that the company adopts conservative accounting policies.

\section{Control variables}

Six control variables dealing with corporate governance and corporate characteristics are included in the model of this study based on previous literature. With regard to corporate governance variables, board size BOSZ is viewed in corporate governance literature as a relevant mechanism that can contribute to enhanced internal control and capability of directors to monitor the actions of firm's management (Samaha et. al, 2015). Thus, I expect an intermediate association 


\section{Nisreen Mohammed Said Almaleeh}

between board size and the degree of accounting conservatism. Board size is measured as the number of directors in the board of directors. The second control variable is the board independence BOIND which refers to the percentage of outside directors on the board.it was found that the existence of independent directors in the board may have a significant impact on the effectiveness of the board's monitoring activities performed by such board to prevent managerial opportunism (Fama\& Jensen, 1983), Accordingly, a positive association is expected between accounting conservatism and board independence (Ahmed\& Duellman, 2007)

With respect to corporate characteristics, it was found that larger firms face higher pressures to report more accurately and that smaller companies are associated with lower reporting quality (Dechow\& Dichev, 2002), corporate size CSIZE is used to control for other factors that affect accounting conservatism, it is measured as the natural logarithm of total assets. Additionally, it is argued that troubled companies have higher motivations to manipulate earnings (Ittonen et. al., 2013). Therefore, the following variables are used as proxies for firm's financial conditions; $L E V$ which refers to leverage measured as the long-term debt scaled by total equity, $O C F$ which is operating cash flows measured as operations cash flows divided by total assets, and $R O A$ which is return on assets measured as net income scaled by total assets.

\section{Empirical models}

To test the empirical validity of the study hypotheses, two panel data models with balanced data were estimated. Panel data analysis refers to the analysis of the same observations at different points of time. The regression models are formulated as follows:

$$
\begin{aligned}
C O N_{-} \text {ACCit }= & \alpha 0+\alpha 1 \text { ACEXPit }+\alpha 2 \text { ACINDit }+\alpha 3 \text { ACSZit }+\alpha 4 \text { ACACit } \\
& +\varepsilon i t \quad(\text { model } 1) \\
\text { CON_ACCit }= & \alpha 0+\alpha 1 \text { ACEXPit }+\alpha 2 \text { ACINDit }+\alpha 3 \text { ACSZit }+\alpha 4 \text { ACACit } \\
& +\alpha 5 \text { BOSZit }+\alpha 6 \text { BOINDit }+\alpha 7 \text { CSIZEit }+\alpha 8 \text { LEVit }+\alpha 9 \\
& \text { OCFit }+\alpha 10 \text { ROAit }+\varepsilon i t \quad \text { (model 2) }
\end{aligned}
$$

Where:

$C O N \_A C C=$ accounting conservatism (dependent variable). 
Scientific Journal for Financial and Commercial Studies and Researches

(SJFCSR) Faculty of Commerce - Damietta University

\section{Independent variables}

$A C E X P=$ Audit committee expertise, $A C I N D=$ Audit committee independence, $A C S Z=$ Audit committee size, $A C A C=$ Audit committee activity.

\section{Control variables}

$B O S Z=$ Board size, $B O I N D=$ Board independence, $C S I Z E=$ Corporate size, $L E V=$ Leverage, $O C F=$ Operating cash flows, $R O A=$ Return on assets.

\section{Results}

\section{Descriptive statistics of data}

The descriptive statistics of the independent, dependent and control variables are shown in table 2 . The table shows that the percentage of audit committee members with financial expertise to total members ranges from $25 \%$ to $100 \%$, while the percentage of independent members to total members ranges from $30 \%$ to $67 \%$. These two indicators are in line with The Egyptian Corporate Governance Code which stated that the audit committee is made up of independent non-executive members with at least one of them have financial and accounting expertise. The mean number of audit committee members is 3 , and they meet at least once a year and at most 15 times a year with a mean of 5 times a year.

As for the accounting conservatism, it is apparent from table 2 that there is a high variability in its value as the standard deviation amounts to 33.6 which indicates that Egyptian companies included in the sample are quite diverse in the extent to which they practice accounting conservatism. the minimum value of accounting conservatism amounts to .31 indicating that there are some companies in the sample that do not use conservative accounting practices, while the maximum value reached 208.1 which indicates using very conservative accounting practices by some companies. Its mean value amounts 9.5 which suggest that most of the companies included in the sample adopts conservative accounting approach. 
Nisreen Mohammed Said Almaleeh

\begin{tabular}{|c|c|c|c|c|}
\hline \multicolumn{5}{|c|}{$\begin{array}{c}\text { Table } 2 \\
\text { Descriptive statistics }\end{array}$} \\
\hline & Minimum & Maximum & Mean & $\begin{array}{c}\text { Std. } \\
\text { Deviation }\end{array}$ \\
\hline ACEXP & .25 & 1.00 & .6416 & .16920 \\
\hline ACIND & .30 & .67 & .5036 & .15125 \\
\hline ACSZ & 2 & 4 & 3.05 & .488 \\
\hline ACAC & 1 & 15 & 5.04 & 3.243 \\
\hline $\mathrm{ACC} C \mathrm{CON}$ & .3080 & 208.1304 & 9.522126 & 33.6114468 \\
\hline BŌSZ & 6 & 15 & 9.47 & 2.387 \\
\hline BOIND & .22 & .91 & .5022 & .17634 \\
\hline CSZ & 3.449096 & 5.016537 & 4.32340323 & .438606934 \\
\hline LEV & -28.906 & 6.427 & -.07903 & 4.218736 \\
\hline $\mathrm{OCF}$ & -.243 & .237 & .02277 & .088158 \\
\hline $\mathrm{ROA}$ & -.07597 & .15009 & .0362561 & .04357476 \\
\hline
\end{tabular}

Turning to control variables, board size is found to range from 6 to 15 members with an average of 10 members, the average percentage of independent members reaches $50 \%$ approximately. The company size measured by the natural logarithm of total assets ranges from 3.45 and 5.02 with an average of 4.32 . The average value of leverage is -.08 , the average of operating cash flows as a percentage of total assets is .09 , and the average return on assets is .04 .

\section{Correlation analysis}

Results of correlation between accounting conservatism and the independent and control variables are reported in Table 3. Results provide evidence that accounting conservatism is positively and significantly associated with audit committee expertise which initially supports the first hypothesis, the association between accounting conservatism and audit committee independence is not significant which suggests the rejection of the second hypothesis.as for audit committee size, table 3 shows that it is negatively and significantly associated with accounting conservatism which is not considered as an initial support to the third hypothesis. Lastly, accounting conservatism and audit committee activity are not significantly associated, which suggests the rejection of the fourth hypothesis. As for the association between accounting conservatism and control variables, the table shows that accounting conservatism is negatively and significantly associated with 
Scientific Journal for Financial and Commercial Studies and Researches

(SJFCSR) Faculty of Commerce - Damietta University

board independence, corporate size, leverage, and return on assets. On the other hand, it was found to be insignificantly related to board size and operating cash flows.

\section{Correlations between dependent and independent variables}

\begin{tabular}{|c|c|c|c|c|c|c|c|c|c|c|c|}
\hline & ACEXP & ACIND & ACSZ & ACAC & $\begin{array}{l}\mathrm{ACC}_{-} \\
\mathrm{CON}\end{array}$ & BOSZ & BOIND & CSZ & LEV & OCF & ROA \\
\hline ACEXP & 1 & & & & & & & & & & \\
\hline ACIND & $.267^{*}$ & 1 & & & & & & & & & \\
\hline ACSZ & $-.544 * *$ & .125 & 1 & & & & & & & & \\
\hline ACAC & -.054 & .167 & -.048 & 1 & & & & & & & \\
\hline $\mathrm{ACC}_{-}$ & $.507^{* *}$ & -.019 & - & -.074 & 1 & & & & & & \\
\hline CON & & & $.538^{* *}$ & & & & & & & & \\
\hline BOSZ & -.239 & 1 & $.343^{*}$ & $.806^{* *}$ & -.254 & 1 & & & & & \\
\hline BOIND & -.165 & .242 & $.578^{* *}$ & .013 & $-.306^{*}$ & $.380^{* *}$ & 1 & & & & \\
\hline \multirow[t]{2}{*}{ CSZ } & -.079 & $-.276^{*}$ & $.344 *$ & .239 & - & $.558^{* *}$ & $.507 * *$ & 1 & & & \\
\hline & & & & & $.354^{* *}$ & & & & & & \\
\hline \multirow[t]{2}{*}{ LEV } & -.244 & .038 & .232 & .137 & - & .121 & .169 & .160 & 1 & & \\
\hline & & & & & $.629^{* *}$ & & & & & & \\
\hline OCF & $.299^{*}$ & $-.297^{*}$ & -.223 & -.053 & .260 & -.129 & -.151 & .038 & -.265 & 1 & \\
\hline \multirow[t]{2}{*}{ ROA } & $-.440^{* *}$ & $-.317^{*}$ & .242 & -.185 & - & -.036 & .158 & .255 & .266 & -.155 & 1 \\
\hline & & & & & $.345 * *$ & & & & & & \\
\hline
\end{tabular}

*Significant at $10 \% ;{ }^{* *}$ significant at $5 \%$

\section{Regression coefficients}

Table 4 reports the results of regressing audit committee characteristics; expertise, independence, size, and activity on accounting conservatism (Model 1). Results indicate that audit committee expertise has a positive and significant effect on accounting conservatism $(\mathrm{t}=$ 2.149 , Sig. $=0.037$ ). Audit committee independence has a negative effect on accounting conservatism, but this effect is insignificant $(\mathrm{t}=-.408$, Sig. $=.685$ ). Audit committee size has a negative significant effect on accounting conservatism $(\mathrm{t}=-2.463$, Sig. $=.017)$. Lastly, audit committee 
Nisreen Mohammed Said Almaleeh

\begin{tabular}{l}
\hline \hline $\begin{array}{l}\text { activity has a negative but insignificant effect on accounting } \\
\text { conservatism }(\mathrm{t}=-.553 \text {, Sig. }=.583) .\end{array}$ \\
\end{tabular}

Table 4

Multiple regression results (model 1)

\begin{tabular}{|l|c|c|c|c|}
\hline & Coefficient & Sig. & Tolerance & VIF \\
\hline Constant & 1.251 & .217 & - & - \\
\hline ACEXP & 2.149 & .037 & .563 & 1.776 \\
\hline ACIND & -.408 & .685 & .770 & 1.298 \\
\hline ACSZ & -2.463 & .017 & .603 & 1.657 \\
\hline ACAC & -.553 & .583 & .934 & 1.071 \\
\hline Model parameters & \multicolumn{5}{|l|}{} \\
\hline Adjusted R ${ }^{2}$ & $31.1 \%$ & - & - & - \\
\hline F & 7.104 & - & - & - \\
\hline Sig. & 0.000 & - & - & - \\
\hline
\end{tabular}

These results are consistent with the results obtained from correlation analysis. Additionally, the values of tolerance for all independent variables is more than .2 , and the values of variance inflation factor (VIF) for all independent variables lies between 1 and 10 which implies there is no multicollinearity i.e., inter-correlations or interassociations among the independent variables. Referring to the entire model, the adjusted $\mathrm{R}^{2}$ is $31.1 \%$ at the level of $1 \%$, which means that audit committee expertise, audit committee independence, audit committee size, and audit committee activity can explain approximately $31.1 \%$ of changes in accounting conservatism.

After adding the control variables (Model 2), the regression results in table 5 showed an improvement in the value of Adjusted R2 (from $31.1 \%$ to $58.3 \%$ ). some results from model (1) are confirmed while other results are modified, As for the first independent variable, audit committee expertise, it is confirmed to have a positive and significant effect on accounting conservatism $(\mathrm{t}=2.785$, Sig. $=.008)$, this result supports the first research hypothesis $\mathrm{H} 1$ which predicts a positive association between the financial expertise of the directors who serve in 
Scientific Journal for Financial and Commercial Studies and Researches (SJFCSR) Faculty of Commerce - Damietta University

the audit committees of the Egyptian firms and the degree of accounting conservatism in their financial statements. As for the second independent variable, audit committee independence, results suggests that it has a negative and significant effect on accounting conservatism $(t=-2.161$, Sig. $=.036$ ), this result does not support the second research hypothesis which predicts a positive association between the independence of the directors who serve in the audit committees of the Egyptian firms and the degree of accounting conservatism in their financial statements.

Table 5

Multiple regression results $(\operatorname{model} 2)$

\begin{tabular}{|c|c|c|c|c|}
\hline & Coefficient & Sig. & Tolerance & VIF \\
\hline Constant & 2.839 & .007 & - & - \\
\hline ACEXP & 2.785 & .008 & .330 & 3.035 \\
\hline ACIND & -2.161 & .036 & .365 & 2.742 \\
\hline ACSZ & -.910 & .038 & .321 & 3.111 \\
\hline ACAC & .487 & .629 & .154 & 6.507 \\
\hline BOSZ & .203 & .840 & .115 & 8.712 \\
\hline BOIND & 1.390 & .171 & .412 & 2.428 \\
\hline $\mathrm{CSZ}$ & -2.624 & .012 & .294 & 3.397 \\
\hline LEV & -4.778 & .000 & .772 & 1.295 \\
\hline $\mathrm{OCF}$ & -.614 & .542 & .688 & 1.453 \\
\hline ROA & -.221 & .826 & .634 & 1.577 \\
\hline \multicolumn{5}{|c|}{ Model parameters } \\
\hline Adjusted $\mathrm{R}^{2}$ & $58.3 \%$ & - & - & - \\
\hline $\mathrm{F}$ & 8.556 & - & - & - \\
\hline Sig. & 0.000 & - & - & - \\
\hline
\end{tabular}

For the third independent variable, audit committee size, results suggest that it has a negative and significant effect on accounting conservatism $(\mathrm{t}=-.910$, Sig. $=.038)$. This result does not support the third research hypothesis which predicts a positive association between the size of the audit committees of the Egyptian firms and the degree of accounting conservatism in their financial statements. Finally, the fourth 


\section{Nisreen Mohammed Said Almaleeh}

independent variable, audit committee activity has a positive but insignificant effect on accounting conservatism $(t=.487$, Sig. $=.629)$ which leads to the rejection of the fourth research hypothesis which predicts a positive association between the activity of audit committees of the Egyptian firms and the degree of accounting conservatism in their financial statements.

\section{Discussion and conclusions}

This study was motivated by the aim of assessing the association between audit committee characteristics; financial expertise, independence, size, and activity and accounting conservatism in the Egyptian listed companies. It also controls for a number of variables that can affect accounting conservatism. This was accomplished depending on a sample of 11 non-financial Egyptian firms listed in the Egyptian Stock Exchange EGX during the period spanning from 2015 to 2019.

The current study found that audit committee expertise is positively associated with the degree of accounting conservatism in the Egyptian listed firms' financial statements. This finding confirms that effective monitoring requires a high degree of specialized financial knowledge which supports the ability to evaluate managerial decisions and enables to monitor senior management efficiently with relatively lower costs for acquiring information about the complexity and risks associated with financial transactions (Harris\& Raviv ,2006; Gore et. al.,2011). This result further supports the findings of previous research which concluded that audit committee effectiveness, and in particular its financial expertise increases the financial reporting quality (Rochmah Ika\& Mohd Ghazali, 2012; Ghafran\& Yasmin, 2018). It also increases accounting conservatism which can be enhanced for several reasons; monitoring and knowledge capabilities of the audit committee members, job expectations as demanded by audit committee charter, and economic incentives for mitigating the litigation risk and protecting reputational capital (Krishnan\& Visvanathan (2008).

In contrast to the previous finding, this study has been unable to find evidence to support the association between audit committee independence and the degree of accounting conservatism in the Egyptian listed firms' financial statements. This result contradicts some previous 
Scientific Journal for Financial and Commercial Studies and Researches

(SJFCSR) Faculty of Commerce - Damietta University

researches which found a positive association between audit committee independence and financial reporting quality as independent members will be objective in monitoring financial reporting process, will play a vital role in reducing management errors and manipulation , and they will not suffer any degree of management's pressures (Klien, 2002; Alqatamin, 2018).In the same vein, previous literature suggested that a higher level of outside directors decreases the probability of fraudulent information in the financial statements(Beasley ,1996; Dechow et.al. ,1996). On the other hand, this result matches those observed in other earlier studies which suggested that higher insider representation play a more effective monitoring role, because inside directors can provide boards with more valuable information as they possess more firmspecific visions and that inside directors play valuable roles that might be absent in a single-minded drive for greater independence (Fama\& Jensen ,1983; Bhagat\& Black ,2001).

Similarly, this study has been unable to find evidence to support the association between audit committee size and the degree of accounting conservatism in the Egyptian listed firms' financial statements. this result is consistent with those of other studies which found that monitoring effectiveness could be enhanced by smaller audit committee size because of better group cohesion and that an increase in the audit committee size may result in less active participation by some members which may in turn ruin group cohesion and undermine the controlling and monitoring functions (Lipton\& Lorsch,1992; Hillman\& Dalziel, 2003).similarly, it was found that a larger committee functions less effectively and is easier to be controlled by the CEO(Jensen ,1993). However, this result differs from other group of researches which argued that larger committees may be more valuable because of possessing a higher degree of available knowledge and experience which enhances the monitoring quality, and that larger committees are more effective in prohibiting corporate failure (Chaganti et. al. ,1985; Xie et.al., 2003; Shukeri\& Islam,2012).

Finally, this study has not been able to find evidence to support the association between audit committee activity and the degree of accounting conservatism in the Egyptian listed firms' financial statements. This result is inconsistent with much of previous literature which reported that the frequent meetings of audit committees enable 


\section{Nisreen Mohammed Said Almaleeh}

them to take timely protective and corrective measures regarding weaknesses of internal control (Khlif \& Samaha, 2016), and that regular meetings will also enable the audit committee to timely detect and prevent the opportunistic behaviour of management and to ensure the integrity of earnings and quality of reported accounting information (Bedard et. al., 2004). A possible explanation for this result may be the great variation in the number of audit committee annual meetings in the study sample as the number of meetings ranged from one meeting to fifteen meetings a year. This is Permissible by The Egyptian Corporate Governance Code (2016) which did not specify the minimum required number of audit committee meetings, although other regulators around the world have recommended an active audit committee with no less than three or four meetings during the year.

These findings have important implications for standard-setters, regulators, firms and investors in Egypt and other developing countries, as they can help in assessing the internal corporate governance mechanisms, particularly the audit committee. As for standard-setters and regulators, results suggest that further attention should be given to promote the financial expertise and independence of the audit committee. Also, the number of audit committee annual meetings should be specified in The Egyptian Corporate Governance Code. As for firms, review is needed to the current definition of independence and more focus should be placed on the composition of audit committee. As for local and international investors, these results could help them in making investment decisions more effectively especially for those who are interested in the effectiveness of audit committees in Egypt after the collapse of different firms all over the world.

However, these results must be interpreted with caution due to several reasons; Firstly, the categorization of audit committee financial expertise, independence, size, and activity is subject to measurement error because of the limited scope of biographical data in the Egyptian setting. Secondly, this study depended on data for the most actively traded companies listed in the Egyptian Stock Market over the period that spans from 2015 till 2019, and may not be generalizable to the population of all firms, especially smaller firms. Finally, because of the complex nature of accounting conservatism, there may be measurement error 
inherent in the proxy used in this study. Despite these limitations, this study contributes to extending the literature on audit committee characteristics by documenting how it relates to the degree of accounting conservatism in the financial statements. However, more research in this topic needs to be undertaken before the association between audit committee characteristics and accounting conservatism is clearly understood.

\section{References}

Abad, C., \& Bravo, F. (2018). Audit committee accounting expertise and forward-looking disclosures: A study of the US companies. Management Research Review, 41(2), 166-185.

Abbott, L. J., \& Parker, S. (2000). Auditor selection and audit committee characteristics. Auditing: A journal of practice \& theory, 19(2), 4766.

Abbott, L. J., \& Parker, S. (2002). Audit committee characteristics and auditor switches. Research in Accounting Regulation, 15, 151-166.

Abbott, L.J., Parker, S. and Peters, G.F. (2004), "Audit committee characteristics and restatements", Auditing: A Journal of Practice and Theory, Vol. 23

Adams, R. B., Hermalin, B. E., \& Weisbach, M. S. (2010). The role of boards of directors in corporate governance: A conceptual framework and survey. Journal of economic literature, 48(1), 58107.

Ahmed, A. S., \& Duellman, S. (2007). Accounting conservatism and board of director characteristics: An empirical analysis. Journal of accounting and economics, 43(2-3), 411-437.

Akhor, S. O., \& Oseghale, E. O. (2017). An empirical investigation of audit committee attributes and financial reporting lag in Nigeria banking sector. Journal of Accounting and Financial Management, 3(2), 25-38.

Alqatamin, R. M. (2018). Audit committee effectiveness and company performance: evidence from Jordan. Accounting and Finance Research, 7(2), 48. 


\section{Nisreen Mohammed Said Almaleeh}

Anderson, R. C., Mansi, S. A., \& Reeb, D. M. (2004). Board characteristics, accounting report integrity, and the cost of debt. Journal of accounting and economics, 37(3), 315-342.

Arun, T. G., Almahrog, Y. E., \& Aribi, Z. A. (2015). Female directors and earnings management: Evidence from UK companies. International Review of Financial Analysis, 39, 137146.

Ball, R., \& Shivakumar, L. (2005). Earnings quality in UK private firms: comparative loss recognition timeliness. Journal of accounting and economics, 39(1), 83-128.

Ball, R., \& Shivakumar, L. (2006). The role of accruals in asymmetrically timely gain and loss recognition. Journal of accounting research, 44(2), 207-242.

Bansal, N., \& Sharma, A. K. (2016). Audit committee, corporate governance and firm performance: Empirical evidence from India. International Journal of Economics and Finance, 8(3), 103.

Basu, S. (1997). The conservatism principle and the asymmetric timeliness of earnings1. Journal of accounting and economics, 24(1), 3-37.

Beasley, M. S. (1996). An empirical analysis of the relation between the board of director composition and financial statement fraud. Accounting review, 443-465.

Beasley, M. S., Carcello, J. V., Hermanson, D. R., \& Lapides, P. D. (2000). Fraudulent financial reporting: Consideration of industry traits and corporate governance mechanisms. Accounting Horizons, 14(4), 441-454.

Beaver, W. H., \& Ryan, S. G. (2000). Biases and lags in book value and their effects on the ability of the book-to-market ratio to predict book return on equity. Journal of accounting research, 38(1), 127148.

Bédard, J., Chtourou, S. M., \& Courteau, L. (2004). The effect of audit committee expertise, independence, and activity on aggressive 
Scientific Journal for Financial and Commercial Studies and Researches

(SJFCSR) Faculty of Commerce - Damietta University

earnings management. Auditing: A Journal of Practice \& Theory, 23(2), 13-35.

Bhagat, S., \& Black, B. (2001). The non-correlation between board independence and long-term firm performance. J. CorP. 1., 27, 231.

Blue Ribbon Committee on Improving the Effectiveness of Corporate Audit Committees. (1999). Report and recommendations of the Blue Ribbon Committee on improving the effectiveness of corporate audit committees. The Business Lawyer, 1067-1095.

Bushman, R. M., \& Piotroski, J. D. (2006). Financial reporting incentives for conservative accounting: The influence of legal and political institutions. Journal of accounting and economics, 42(1-2), 107148.

Carcello, J. V., Neal, T. L., Palmrose, Z. V., \& Scholz, S. (2011). CEO involvement in selecting board members, audit committee effectiveness, and restatements. Contemporary Accounting Research, 28(2), 396-430.

Chaganti, R. S., Mahajan, V., \& Sharma, S. (1985). Corporate board size, composition and corporate failures in retailing industry [1]. Journal of management studies, 22(4), 400-417.

Cullinan, C. P., Wang, F., Wang, P., \& Zhang, J. (2012). Ownership structure and accounting conservatism in China. Journal of International Accounting, Auditing and Taxation, 21(1), 1-16.

De Andres, P., \& Vallelado, E. (2008). Corporate governance in banking: The role of the board of directors. Journal of banking \& finance, 32(12), 2570-2580.

Dechow, P. M., \& Dichev, I. D. (2002). The quality of accruals and earnings: The role of accrual estimation errors. The accounting review, 77(s-1), 35-59.

Dechow, P. M., Sloan, R. G., \& Sweeney, A. P. (1996). Causes and consequences of earnings manipulation: An analysis of firms subject to enforcement actions by the SEC. Contemporary accounting research, 13(1), 1-36. 


\section{Nisreen Mohammed Said Almaleeh}

Fama, E. F., \& Jensen, M. C. (1983). Separation of ownership and control. The journal of law and Economics, 26(2), 301-325.

Farber, D. B. (2005). Restoring trust after fraud: Does corporate governance matter?. The Accounting Review, 80(2), 539-561.

Feltham, G. A., \& Ohlson, J. A. (1995). Valuation and clean surplus accounting for operating and financial activities. Contemporary accounting research, 11(2), 689-731.

Francis, J., LaFond, R., Olsson, P., \& Schipper, K. (2005). The market pricing of accruals quality. Journal of accounting and economics, 39(2), 295-327.

Garcia-Meca, E., \& Sanchez-Ballesta, J. P. (2010). The association of board independence and ownership concentration with voluntary disclosure: A meta-analysis. European Accounting Review, 19(3), 603-627.

Garcia-Sanchez, I. M., Martínez-Ferrero, J., \& García-Meca, E. (2017). Gender diversity, financial expertise and its effects on accounting quality. Management Decision, 55(2), 347-382.

Ghafran, C., \& Yasmin, S. (2018). Audit committee chair and financial reporting timeliness: A focus on financial, experiential and monitoring expertise. International Journal of Auditing, 22(1), 1324.

Gillan, S. L. (2006). Recent developments in corporate governance: An overview.

Givoly, D., \& Hayn, C. (2000). The changing time-series properties of earnings, cash flows and accruals: Has financial reporting become more conservative? Journal of accounting and economics, 29(3), 287-320.

Gore, A. K., Matsunaga, S., \& Eric Yeung, P. (2011). The role of technical expertise in firm governance structure: Evidence from chief financial officer contractual incentives. Strategic Management Journal, 32(7), 771-786. 
Scientific Journal for Financial and Commercial Studies and Researches (SJFCSR) Faculty of Commerce - Damietta University

Habbash, M., \& Alagla, S. (2016). Audit Committee Effectiveness and Audit Quality: Evidence from Saudi Arabia. Journal Of Administrative And Economics Science, 8(2).

Harris, M., \& Raviv, A. (2006). A theory of board control and size. The Review of Financial Studies, 21(4), 1797-1832.

Hillman, A. J., \& Dalziel, T. (2003). Boards of directors and firm performance: Integrating agency and resource dependence perspectives. Academy of Management review, 28(3), 383-396.

Hu, J., Li, A. Y., \& Zhang, F. F. (2014). Does accounting conservatism improve the corporate information environment?. Journal of international accounting, Auditing and Taxation, 23(1), 32-43.

Inaam, Z., \& Khamoussi, H. (2016). Audit committee effectiveness, audit quality and earnings management: a meta-analysis. International Journal of Law and Management, 58(2), 179-196.

Ittonen, K., Vähämaa, E., \& Vähämaa, S. (2013). Female auditors and accruals quality. Accounting Horizons, 27(2), 205-228.

Jensen, M. C. (1993). The modern industrial revolution, exit, and the failure of internal control systems. the Journal of Finance, 48(3), 831-880.

Jensen, M. C., \& Meckling, W. H. (1976). Theory of the firm: Managerial behavior, agency costs and ownership structure. Journal of financial economics, 3(4), 305-360.

Khlif, H., \& Samaha, K. (2016). Audit committee activity and internal control quality in Egypt. Managerial Auditing Journal.

Klein, A. (2002). Audit committee, board of director characteristics, and earnings management. Journal of accounting and economics, 33(3), $375-400$.

Krishnan, G. V., \& Visvanathan, G. (2008). Does the SOX definition of an accounting expert matter? The association between audit committee directors' accounting expertise and accounting conservatism. Contemporary Accounting Research, 25(3), 827-858. 


\section{Nisreen Mohammed Said Almaleeh}

Krishnan, J. (2005). Audit committee quality and internal control: An empirical analysis. The accounting review, 80(2), 649-675.

LaFond, R., \& Watts, R. L. (2008). The information role of conservatism. The Accounting Review, 83(2), 447-478.

Leventis, S., Dimitropoulos, P., \& Owusu - Ansah, S. (2013). Corporate governance and accounting conservatism: Evidence from the banking industry. Corporate Governance: An International Review, 21(3), 264-286.

Levitt, A. (2004). Evidence on the relation between corporate governance characteristics and the quality of financial reporting.

Lim, R. (2011). Are corporate governance attributes associated with accounting conservatism?. Accounting \& Finance, 51(4), 10071030 .

Lin, H. (2006). Accounting discretion and managerial conservatism: An intertemporal analysis. Contemporary Accounting Research, 23(4), 1017-1041.

Lin, J. W., \& Hwang, M. I. (2010). Audit quality, corporate governance, and earnings management: A meta - analysis. International Journal of Auditing, 14(1), 57-77.

Lipton, M., \& Lorsch, J. W. (1992). A modest proposal for improved corporate governance. The business lawyer, 59-77.

Menon, K., \& Williams, J. D. (1994). The use of audit committees for monitoring. Journal of Accounting and public Policy, 13(2), 121139.

Muttakin, M. B., Khan, A., \& Tanewski, G. (2019). CFO tenure, CFO board membership and accounting conservatism. Journal of Contemporary Accounting \& Economics, 15(3), 100165.

Naimi, M., Nor, M., Rohami, S., \& Wan-Hussin, W. N. (2010). Corporate governance and audit report lag in Malaysia. (October 20, 2010). Asian Academy of Management Journal of Accounting and Finance, 6(2). 
Scientific Journal for Financial and Commercial Studies and Researches (SJFCSR) Faculty of Commerce - Damietta University

Penman, S. H., \& Zhang, X. J. (2002). Accounting conservatism, the quality of earnings, and stock returns. The accounting review, 77(2), 237-264.

Raghunandan, K., Rama, D. V., \& Read, W. J. (2001). Audit committee composition, "gray directors," and interaction with internal auditing. Accounting Horizons, 15(2), 105-118.

Rainsbury, E. A., Bradbury, M., \& Cahan, S. F. (2009). The impact of audit committee quality on financial reporting quality and audit fees. Journal of Contemporary Accounting \& Economics, 5(1), 2033.

Rochmah Ika, S., \& Mohd Ghazali, N. A. (2012). Audit committee effectiveness and timeliness of reporting: Indonesian evidence. Managerial Auditing Journal, 27(4), 403-424.

Samaha, K., Khlif, H., \& Hussainey, K. (2015). The impact of board and audit committee characteristics on voluntary disclosure: A metaanalysis. Journal of International Accounting, Auditing and Taxation, 24, 13-28.

Shukeri, S. N., \& Islam, M. A. (2012). The determinants of audit timeliness: Evidence from Malaysia. Journal of Applied Sciences Research, 8(7), 3314-3322.

Sultana, N., Singh, H., \& Van der Zahn, J. L. M. (2015). Audit committee characteristics and audit report lag. International Journal of Auditing, 19(2), 72-87.

Sun, J., Liu, G., \& Lan, G. (2011). Does female directorship on independent audit committees constrain earnings management?. Journal of Business Ethics, 99(3), 369-382.

The Egyptian Corporate Governance Code (August 2016), third release, issued by Egyptian Institute of Directors (EIoD).available at: www.eiof.org

Vafeas, N. (2000). Board structure and the informativeness of earnings. Journal of Accounting and Public policy, 19(2), 139-160. 


\section{Nisreen Mohammed Said Almaleeh}

Verriest, A., Gaeremynck, A. and Thornton, D. (2012), "The impact of corporate governance on IFRS adoption choices", European Accounting Review, Vol. 22 No. 1, pp. 39-77.

Watts, R. L. (2003). Conservatism in accounting part I: Explanations and implications. Accounting horizons, 17(3), 207-221.

Wright, D. W. (1996). Evidence on the relation between corporate governance characteristics and the quality of financial reporting (No. 9601). University of Michigan.

Xie, B., Davidson III, W. N., \& DaDalt, P. J. (2003). Earnings management and corporate governance: the role of the board and the audit committee. Journal of corporate finance, 9(3), 295-316.

Zalata, A. M., Tauringana, V., \& Tingbani, I. (2018). Audit committee financial expertise, gender, and earnings management: Does gender of the financial expert matter?. International review of financial analysis, 55, 170-183.

Zhang, J. (2008). The contracting benefits of accounting conservatism to lenders and borrowers. Journal of accounting and economics, 45(1), 27-54.

Zhang, X. J. (2000). Conservative accounting and equity valuation. Journal of Accounting and Economics, 29(1), 125-149. 
Scientific Journal for Financial and Commercial Studies and Researches (SJFCSR) Faculty of Commerce - Damietta University

\section{خصائص لجنتا المراجعتوالتحفظ المحاسبي: دراست تطبيقيت}

\section{نسرين محمد سعيد المليح}

مدرس المحاسبة بكلية التجارة- جامعة المنوفية

$$
\text { ملخص البحث }
$$

يهدف البحث إلى استكثاف العلاقة بين خصائص لجنة المراجعة (الخبرة، الاستقلالية،

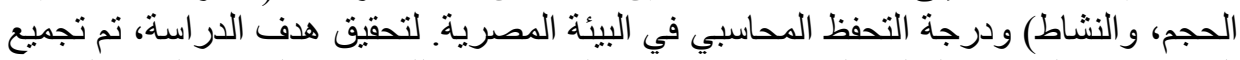

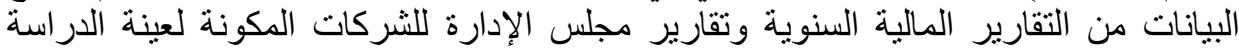

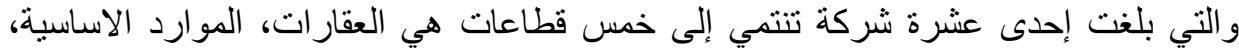

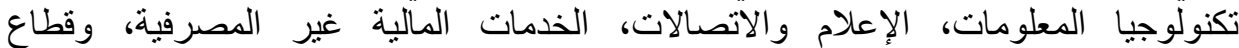

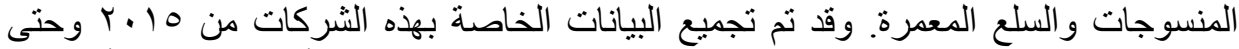

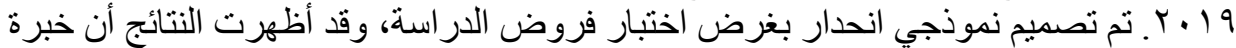

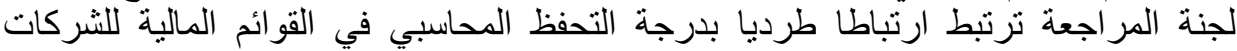

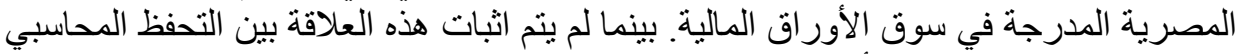

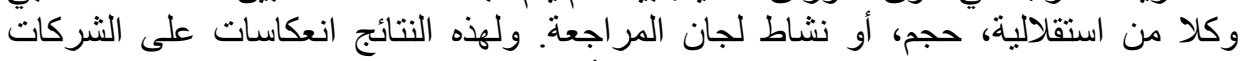

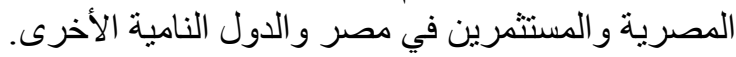

\section{الكلمات المفتاحيتة:}

خصائص لجنة المراجعة، التحفظ المحاسبي، استقلالية لجنة المراجعة، حجم لجنة المر اجعة، خبرة لجنة المر اجعة. 